\title{
Productivity effects of internationalisation through the domestic supply chain
}

\author{
Bruno Merlevede, Angelos Theodorakopoulos 24 January 2019
}

Studies of the implications of trade openness for local economies rarely address the domestic supply chain. This column examines whether indirect effects of internationalisation affect the domestic supply chain. Microlevel data for manufacturing firms across 19 EU countries, combined with input-output tables, show that domestic access to intermediate inputs that are also exported leads to higher levels of efficiency.

16

A $\mathbf{A}$

Substantial decreases in trade and communication costs in recent decades have increasingly fragmented production, both within and across national boundaries (Antràs et al. 2012). A large body of research examines the effect of importing and exporting behaviour by firms or industries on productivity, and its determinants (see Shu and Steiweinder 2019 for a review of this research).

The potential productivity effects of internationalisation along the domestic supply chain have, however, received less attention. One exception is Blalock and Veloso (2007), who find that the productivity of domestic suppliers increases when their clients also import. Since firms are more likely to share knowledge with partners along a supply chain than with competitors, local firms that participate in the domestic supply chain may experience indirect productivity effects from internationalisation.

It is important that we understand this link for several reasons.

- It sheds light on how firm- and industry-level ties shape the diffusion of knowledge and technologies that are important factors in economic growth.

- It brings new insights into the impact of globalisation on complex modern economies.

- We can better understand the potential causes of Europe's productivity puzzle and anaemic growth in relation to the current phase of globalisation.

\section{Accounting for the domestic supply chain}

In a recent paper (Merlevede and Theodorakopoulos 2018), we explore how the internationalisation behaviour of a firm's local clients and suppliers affect its productivity, by analysing the import and export of intermediate inputs by vertically related firms. ${ }^{1}$

Research until now has shown the direct and indirect methods through which firms can learn and improve, boosting their productivity. On the one hand, learning can be relationship-specific when production coordinates inputs from many firms (Kellogg 2011). In this case, knowledge is acquired through interactions between producers and providers of intermediate inputs. On the other hand, learning can be derived from performing tasks such as organisational restructuring, network sharing, revamping technical and managerial practices, and transferring knowledge. ${ }^{2}$ Indirect competition may also incentivise firms to innovate, upgrade quality, and save costs. In our analysis, we associate this learning process with supplying (sourcing) intermediate inputs to upstream (from downstream) sectors that also export or import.

\section{Pass-on productivity effects of internationalisation}

We analyse two direct and two indirect channels of possible productivity effects for a given firm e domestic supply chain (Figure 1). Direct channels are driven by trade in intermediates in Idustries, but this is not the case for indirect channels.

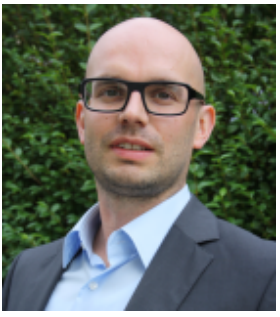

Bruno Merlevede Professor of Economics, Ghent University

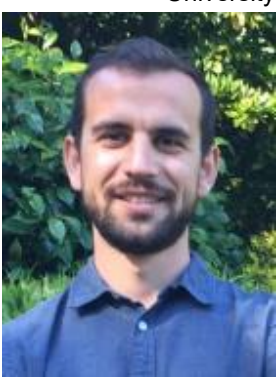

Angelos

Theodorakopoulos Post-doctoral Fellow Oxford Martin School - University of Oxford Oxford Martin Programme on Technological and Economic Change, University of Oxford

\section{Don't Miss}

Taxing the superrich Scheuer

Pre-distribution versus redistribution

Bozio, Garbinti, Goupille-Lebret, Guillot, Piketty

Revitalising multilateralism: A new eBook

Evenett, Baldwin

\section{Events}

CEPR Household Finance

Seminar Series - 11 27 - 27 November 2020 / Online /

Geneva Trade and Development Workshop 30 November - 14 December 2020 / Online / CEPR, the Graduate Institute Geneva, GSEM, UNCTAD and the World Trade Organization.

CEPR Advanced Forum in Financial Economics 8 December 2020 - 8 June 2021 / Online seminar / CEPR

7th Empirical Management Conference - Virtual Edition - 10 December 2020 / Online / Cornell University

Young Scholars Conference 2020

10 - 11 December 2020 /

Online / 


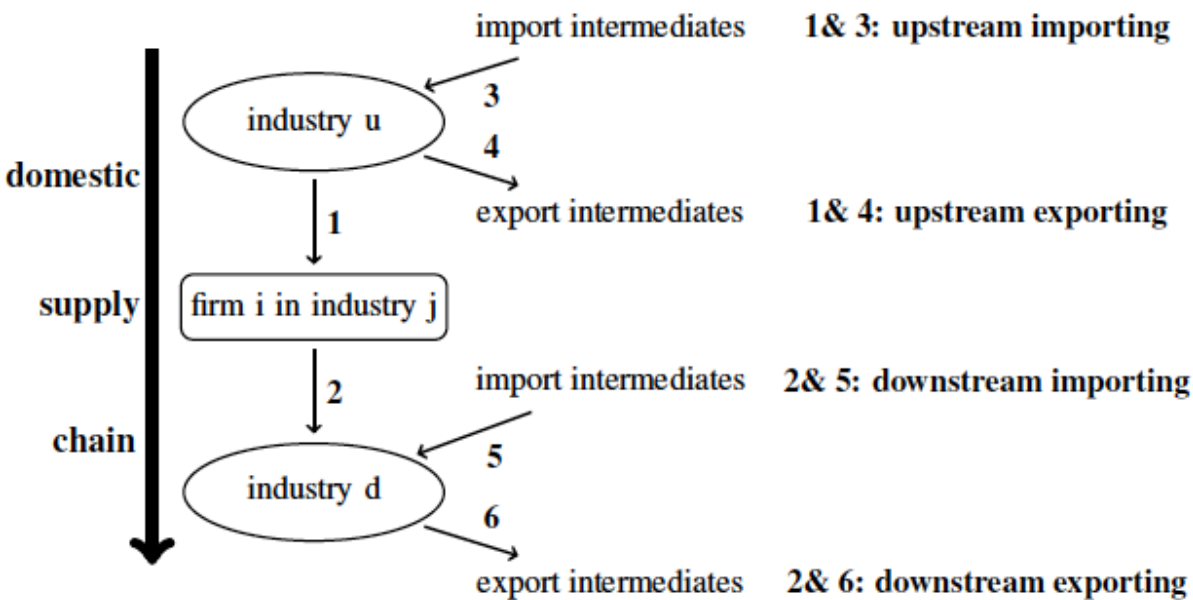

Source: Merlevede and Theodorakopoulos (2018)

\section{Direct channels}

A firm's local supplier may also export the intermediates that the firm sources (steps 1 and 4). For example, an electronics firm might supply intermediates to a domestic electrical equipment firm and export the same intermediates abroad. This could induce positive productivity effects in the electrical equipment firm if exporting increases the quality and range of the set of domestically available intermediate inputs supplied by the electronics firm. ${ }^{3}$ A firm's local client may also source intermediates from abroad (steps 2 and 5). Faced with foreign competition, domestic firms must reduce costs (and improve productivity) to survive. Alternatively, upgrading production processes may create productivity effects if the intermediates are complements to those imported by downstream firms (Blalock and Veloso 2007). ${ }^{4}$

\section{Indirect channels}

A firm's local supplier may import intermediates itself (steps 1 and 3 ). This spurs learning through knowledge diffusion from upstream to downstream industries (Grossman and Helpman 1995). A firm's local client may also export its output (steps 2 and 6). Possibly because export oriented, downstream clients demand increased quality of intermediate inputs.

\section{Putting the pieces together}

We empirically model potential productivity effects from inter-industry importing and exporting as a learning process, in which past experience gained through the channels described above affects current productivity. We estimate production functions using the procedure proposed by Gandhi et. al (2018).

We combine rich firm-level data for manufacturing firms from $19 \mathrm{EU}$ countries ${ }^{5}$ (Merlevede et. al 2015) with the 2016 release of the World Input-Output (IO) Tables (Timmer et al. 2016) between 2000 and 2014. Our firm-level dataset contains all the balance sheet information we need to estimate the firms' production function (and hence their productivity). We then use IO tables to construct the measures of inter-industry importing and exporting intensities that we need.

\section{Upstream exporting boosts productivity}

We find that sourcing from domestic industries that also export intermediate goods is associated with higher productivity levels for a given firm (upstream exporting is steps 1 and 4 in Figure 1). This is the only robust channel through which productivity effects of internationalisation occur through the domestic supply chain. ${ }^{6}$ We argue that the observed effect stems from access to higher quality inputs, which are also exported. Nonetheless, this need not be the only mechanism, as our results capture any potential learning process arising from this relationship (for example, organisational practices or export network).

Our results indicate that a one standard deviation increase in upstream exporting is associated with a productivity increase of $1.13 \%$ in the short run, and $2.50 \%$ in the long run. This implies that the domestic supply chain achieves indirect productivity effects from internationalisation. This effect is stronger for firms and industries that are less likely to be already (directly) internationally involved. ally, our findings suggest that the effect is more prominent for firms without foreign

Discussion Papers Insights
Homeownership of
immigrants in France:
selection effects related to
international migration flows
Gobillon, Solignac
Climate Change and Long-
Run Discount Rates:
Evidence from Real Estate
Giglio, Maggiori, Stroebel,
Weber
The Permanent Effects of
Fiscal Consolidations
Summers, Fatás
Demographics and the
Secular Stagnation
Hypothesis in Europe
Favero, Galasso
QE and the Bank Lending
Channel in the United
Kingdom
Butt, Churm, McMahon,
Morotz, Schanz

\section{Subscribe}

@VoxEU

RSS Feeds

Weekly Digest 
ownership links, and for firms in industries which are relatively downstream, low-tech, or capital intensive.

\section{Summary}

This bridges the gap between the domestic and global supply chains and contributes to our understanding about the overall effects of internationalisation on local economies. We provide new evidence that internationalisation can boost productivity through the domestic supply chain.

This analysis is empirical. We also see rich potential for findings to motivate theoretical work on firm heterogeneity, supply chains, and trade. This could help to structure our understanding of the mechanisms driving our empirical findings, and allow us to generate counterfactual predictions about patterns of trade, production, and productivity from changes in policies related to internationalisation.

\section{References}

Antràs, P, D Chor, T Fally, and R Hillberry (2012), "Measuring the upstreamness of production and trade flows", American Economic Review: Papers and Proceedings 102(3): 412-416.

Blalock, G and F M Veloso (2007), "Imports, productivity growth, and supply chain learning", World Development 35(7): 1134-1151.

Gandhi, A, S Navarro, and D Rivers (2018), "On the identification of gross output production functions", conditionally accepted by the Journal of Political Economy.

Grossman, G M and E Helpman (1995), "Technology and trade", in G M Grossman and K Rogoff, Handbook of International Economics, Volume 3, Elsevier.

Javorcik, B S (2004), "Does foreign direct investment increase the productivity of domestic firms? In search of spillovers through backward linkages", American Economic Review 94(3): 605-627.

Jovanovic, B and Y Nyarko (1996), "Learning by doing and the choice of technology", Econometrica 64(6): 1299-1310.

Kellogg, R (2011), "Learning by drilling: Interfirm learning and relationship persistence in the Texas oilpatch", Quarterly Journal of Economics 126(4): 1961-2004.

Merlevede, B, M de Zwaan, K Lenaerts, and V Purice (2015), "Multinational networks, domestic, and foreign firms in Europe", Ghent University Faculty of Economics working paper D/2015/7012/02.

Merlevede, B and A Theodorakopoulos (2018), "Productivity effects of internationalisation through the domestic supply chain: Evidence from Europe", KU Leuven Faculty of Economics and Business - VIVES Discussion Paper 71.

Shu, P and C Steinwender (2019), "The impact of trade liberalization on firm productivity and innovation", Innovation Policy and the Economy 19: 39-68.

Timmer, M P, B Los, R Stehrer, and G J de Vries (2016), An anatomy of the global trade slowdown based on the WIOD 2016 release, Technical report, Groningen Growth and Development Centre, University of Groningen.

\section{Endnotes}

[1] The mechanisms we have in mind bear close resemblance to vertical productivity effects from foreign direct investment (FDI), as in Javorcik (2004).

[2] These mechanisms are explored in detail in Jovanovic and Nyarko (1996) among others.

[3] Potential productivity effects may also extend to more indirect mechanisms such as diffusion of management practices, benefits from international networking, and organisational restructuring.

[4] This stems from matching the specificities and quality standards of the complementary intermediate inputs used in the production process of downstream firms.

[5] Austria; Belgium; Bulgaria; Croatia; Czech Republic; Estonia; Finland; France; Germany; Hungary; Italy; Norway; Poland; Portugal; Romania; Slovakia; Slovenia; Spain; and Sweden. 
under certain robustness checks.

Topics: Industrial organisation International trade

Tags: exporting, importing, supply chain, Intermediate inputs, total factor productivity, learning

\section{Related}

Value chain integration: Export-oriented versus domestic-oriented firms

Bernhard Michel, Caroline Hambÿe, Bart Hertveldt

The network origins of the gains from trade

Maarten Bosker, Bastian Westbrock

The impact of free trade on domestic industries

Shujiro Urata, Atsuyuki Kato

Printer-friendly version 